\title{
Effect of Temperature, Time and Amount of Alkaline Treated Cotton Seaweed (ATS) Products Dried in a Dryer Oven on Product Quality
}

\author{
Mochammad Masud ${ }^{1}$, Mohammad Effendi ${ }^{1}$, Miftachul Huda ${ }^{1}$ \\ ${ }^{1}$ Department of Mechanical Engineering, University of Yudharta, Pasuruan, Indonesia \\ Email: masud.teknik@yudharta.ac.id
}

\begin{abstract}
Eucheuma cottonii seaweed contains carrageenan, which is used as an ingredient for the food and beverage industry. This must be processed first by an alkaline process and then dried to become chips known as alkaline treated cotton chips (ATC) products. The process of drying seaweed was done using an oven dryer using heat energy that can be adjusted to the drying time, temperature and number of products so that the quality of the dried products of seaweed products that have been processed into Alkaline Treated Cotton Seaweed (ATS) to be used as an advanced product becomes ATC (Alkali Treated Cotton Chips). The results of this study aim to find out the optimal value of temperature, drying time and the amount of ATS to get output from ATC in accordance with SNI 8170: 2015 standard and received by the customer. Based on the results of the study, it was found that the minimum significant drying process for moisture content was $12.10 \%$ at level $2,1 \mathrm{~kg}$ weight, level 2 temperature $70^{\circ} \mathrm{C}$ with level 3 drying time 400 minutes. Whereas the maximum gel strength is 910 gram / cm 2 at level 1, weight $0.5 \mathrm{~kg}$, level 2 temperature $70{ }^{\circ} \mathrm{C}$ with level 2 drying time 320 minutes.
\end{abstract}

Keywords Echeuma cottonii, drying, moisture content, gel strength

Paper type Research paper

\section{INTRODUCTION}

Indonesia is the largest producer of cottony seaweed in the world. Based on data from the Ministry of Maritime Affairs and Fisheries (2012), the national seaweed production volume in 2011 reached 416,272 tons of dry weight and about 349,792 tons of the type of Eucheuma cottonii) [1]. Where one of these types of seaweed contains carrageenan which is used as an additive (ingredient) for the food and beverage industry. Seaweed (seaweed) in scientific languages is known as algae. Based on the pigments contained, Eucheuma cottonii is a seaweed from the Rhodopyceae (red algae) group which can produce variety that is widely used in various industries. Before it is made into cottony seaweed ingredients, it must be processed first with an alkaline process and then dried to become chips known as chips. alkaline products treated cotton chips (ATC). This drying process is mostly done by using solar heat. Seaweed drying done by utilizing solar heat is quite efficient in terms of drying costs, but with the current weather conditions affecting the time and quality of dried yields of seaweed products that have been processed into Alkali Treated Cotton Seaweed (ATS) to be used as a product continued to be ATC (Alkali Treated Cotton Chips). Weather conditions that are often cloudy or erratic affect the productivity of this ATC and if exposed to rain / dew with imperfect closure it will reduce the quality of this ATC. To achieve productivity that can be targeted, it is necessary to do a drying process that is not dependent on the weather that is using an oven dryer machine using heat energy so that it can dry ATS and can directly be processed into ATC after leaving the oven dryer.

The purer the level of the dealer the higher the market value, the more complex technology and higher production costs are needed. In the high temperature process $(\mathrm{KOH})$ used to reduce sulfate content in seaweed, the $\mathrm{K}+$ cation separated from $\mathrm{KOH}$ will affect the strength of the ATC gel which is usually used as a quality parameter. Producing high quality ATC will also be affected by the drying process which is expected to produce 12-14\% of water content. The cutting step before or after drying will affect the quality of ATC, especially the strength of the gel [2].

In the experiment using the oven dryer the optimum time of seaweed drying at 4 hours with a temperature of $650 \mathrm{C}$ where the moisture content obtained is $0.1608 \mathrm{~kg}$ water $/ \mathrm{kg} \mathrm{RL}$, this indicates there is still a lot of water content in seaweed, so it takes a long time by increasing operating temperature [3]. The maximum level of dryness of this ATC product is 15\% water content according to SNI 8170: 2015 Alkali treated Seaweed Chips.

The extraction process is carried out to produce a concentration of $\mathrm{KCl}$ solution that provides a good structure of the structure with the aim of facilitating the further process of seaweed extraction. The process is more optimal at a concentration of $1 \%$ and $1.5 \% \mathrm{KCl}$ solution at a temperature of $300 \mathrm{C}$ clear brownish, irregular shape, slightly hard and 


\section{Effect of Temperature, Time and Amount of Alkaline Treated Cotton Seaweed (ATS) Products Dried in a Dryer Oven on Product Quality}

not taste, whereas at the strength of Gel $1897.14 \mathrm{~g} / \mathrm{cm} 2$ [4]. The heavier the load is needed, the higher the gel strength will be. The strength of the gel is very important to determine the treatment for which the ability to form a gel is one of the carrageenan properties that is the basis of use in various industries. Gel strength will increase directly proportional to $\mathrm{KOH}$, temperature, interaction between time and interaction between $\mathrm{KOH}$ concentration and temperature. The response of gel strength will decrease with increasing time, interaction between $\mathrm{KOH}$ concentration and temperature, interaction between $\mathrm{KOH}$ concentration with time and between $\mathrm{KOH}$ concentration. The increase and decrease in temperature is significantly only influenced by the temperature component and $\mathrm{KOH}$ concentration. This is because an increase in temperature accelerates the process of transformation of sulfate groups by $\mathrm{K}+$ ions from $\mathrm{KOH}$ solution and forms dissolved potassium sulfate [5].

the best in carrageenan processing in this research it was expected to make a process factor that can affect the quality of the product at the level of dryness of this ATC product is a maximum of $15 \%$ of the water content according to SNI 8170: 2015 Alkali Treated Seaweed Chips and yellow brown color. The analytical method uses Taguchi's Analysis of Variant (ANOVA).

\section{Drying Process}

Seaweed raw material naturally has a large enough water content when fresh it has $75-85 \%$ water content and $15-25 \%$ organic and mineral components. The process of drying fresh seaweed is an important process before it is used in the seaweed processing industry process [6]. The production process of this seaweed processing type Euchema cottoni is not too complicated if it only makes this product into a semi-finished material, namely Alkali Treated Cotton chips. The drying process using a drying machine in this case is a type of oven dryer.

Drying is a series of complicated operations that include heat and mass transfer throughout the process. The drying rate of carrageenan using an oven dryer is faster than the microwave dryer, the gel strength value in the oven will be greater, namely $108.6770 \mathrm{gr} / \mathrm{cm} 2$ ) [7]. To find out the time and temperature of the operation in the drying process and to understand the drying process. Based on the research results of dry mass of seaweed in 150 grams of 12.75 grams and the optimum conditions in the process of drying seaweed, drying time 4 hours with a temperature of $65^{\circ} \mathrm{C}$ and the remaining water content in seaweed by 1.36\%) [8]. Drying or dehydration process associated with reducing the water content or moisture in food so that it can inhibit the growth of microbes and / or reduce the occurrence of adverse chemical reactions) [9]. The value of the wet ATS water content is calculated before entering the oven dryer to determine the rate of drying ATS drying rate [10]. Design and testing of solar for drying and kinetics of seaweed in Malaysia. drying process of alkali treated cottonii seaweed is drying in a certain amount to reduce the water content to reach a maximum of $15 \%$ with a batch or continuous system (batch drying). Drying using oven drying is a batch drying system where alkali treated cottonii seaweed is put into the oven with a certain temperature setting and with a certain time so that the water content can be reached in accordance with existing standards. Where the yield of seaweed is $30 \%$. ie to find the initial weight is the weight of the product number times the yield of seaweed. The water content of the material (X) can be calculated on a dry basis with the formula:

$$
\begin{aligned}
& \mathrm{X}=\frac{w(t)-d}{d} \mathrm{X} 100 \% \\
& \text { where: } \\
& \begin{array}{l}
\mathrm{w}(\mathrm{t}) \quad=\text { mass of wet seaweed }(\mathrm{kg}) \\
\mathrm{d} \quad=\text { mass of dried seaweed }(\mathrm{kg})
\end{array}
\end{aligned}
$$

There are two groups of factors that influence drying, namely factors related to drying air and factors related to the nature of the dried material. Factors included in the first class are temperature, volumetric speed of drying air flow and humidity. Factors included in the second group are material size, initial moisture content and partial pressure in the material. Moisture affects the water vapor removal process. If the humidity is high, the difference in water vapor pressure inside and outside the material becomes small so that it prevents the transfer of water vapor from inside the material to the outside. Control of temperature and drying time is done by regulating the dryer with a heater, such as hot air flow or other heating devices. The drying temperature will affect the humidity of the air inside the dryer and the drying rate for the material. The higher the temperature and duration of drying, the greater the thermal energy under the air so that the amount of mass of liquid that is evaporated on the surface of the product more and more) [11]. Moisture content of carrageenan products are influenced by the temperature and speed of the drying air entering the column. The results of carrageenan with the lowest water content of $11.35 \%$ were achieved in the process conditions with a column temperature of $125^{\circ} \mathrm{C}$ with a drying air speed of $14 \mathrm{~m} / \mathrm{sec}$. The gel strength of carrageenan products at the same temperature increases with the higher drying air velocity. The strength of the gel produced at an air velocity of $14 \mathrm{~m} / \mathrm{sec}$ is $116 \mathrm{~g} /$ $\mathrm{cm})$ [12]. At high humidity, the rate of evaporation of material water will be slower than drying at low humidity.

\section{Calculation of S/N Ratio}

The $\mathrm{S} / \mathrm{N}$ ratio is used to select factors that have contributed to reducing the variation in a response. $\mathrm{S} / \mathrm{N}$ ratio is a design for data repetition transformation into a value which is a measure of variation that some rises. Using $\mathrm{S} / \mathrm{N}$ ratio to find out which level factor influences the experimental results [13] Calculation of S / N Ratio Calculation of S / N ratio value depends on the type of quality characteristics of the response. Response moister content quality characteristics 
the smaller the better. The $\mathrm{S} / \mathrm{N}$ ratio for the moisture content is calculated using equation 1.2. For example, the calculation of the $\mathrm{S} / \mathrm{N}$ ratio for the moisture content is as follows.

$$
\mathrm{S} / \mathrm{N}=-10 \log \left(\frac{1}{n} \sum_{i=1}^{r} \gamma_{i}^{2}\right)
$$

As for the response of gel strength characteristics of the quality is the greater the better. The ratio for $\mathrm{S} / \mathrm{N}$ for gel strength can be calculated with equation 1.3 For example calculation of the ratio of $\mathrm{S} / \mathrm{N}$ gel strength is as follows.

$$
\mathrm{S} / \mathrm{N}=-10 \log \left(\frac{1}{n} \sum_{i=1}^{r} \frac{1}{\gamma_{i}^{2}}\right)
$$

\section{METHOD}

Planning Phase: Selecting process factors that affect product quality, namely temperature (600C, 700C and 800C), dry time (240 minutes, 320 minutes and 400 minutes) and the number of products $(0.5 \mathrm{~kg}, 1.5 \mathrm{~kg}$ and $1 \mathrm{~kg})$ in the oven dryer which we then determine the level with three replications. The design of this experiment begins with the selection of an orthogonal matrix which depends on the number of control variables and the level then calculates the degree of freedom to determine the orthogonal matrix.

TABLE 1. TOTAL DEGREES OF FREEDOM OF INDEPENDENT VARIABLES AND THEIR LEVELS

\begin{tabular}{ccc}
\hline Independent Variable & $\begin{array}{c}\text { Quantity of } \\
\text { Level (k) }\end{array}$ & vn(k-1) \\
\hline Mass, $\mathrm{m}(\mathrm{kg})$ & 3 & 2 \\
Temperature, T $\left({ }^{\circ} \mathrm{C}\right)$ & 3 & 2 \\
Drying time, $\mathrm{t}($ minutes $)$ & 3 & 2 \\
\hline Total of & & 6 \\
\hline
\end{tabular}

From the calculation results obtained 6 degrees of freedom for this experiment, so the orthogonal matrix used is L9 (34). It is known that for orthogonal matrix L9 has 9 rows and 4 columns which can be used for four independent variables, each of which has 3 levels. This research can be done with an experimental design which can be seen in table 1.2

TABLE 2. ORTHOGONAL MATRIC OF EXPERIMENT

\begin{tabular}{cccc}
\hline \multirow{2}{*}{ No } & \multicolumn{3}{c}{ Drying process parameter } \\
\cline { 2 - 4 } & Mass & Temperature & Time \\
\hline 1 & 1 & 1 & 1 \\
2 & 1 & 2 & 2 \\
3 & 1 & 3 & 3 \\
4 & 2 & 1 & 2 \\
5 & 2 & 2 & 3 \\
6 & 2 & 1 & 1 \\
7 & 3 & 2 & 3 \\
8 & 3 & 3 & 1 \\
9 & 3 & & 2 \\
\hline
\end{tabular}

Retrieval of experimental data is carried out randomly with a combination of parameters in accordance with the orthogonal matrix design experiments in table 1.2 The combination of these parameters was made with the help of the Minitab program. Each parameter combination was repeated three times and then the average value was taken.

Implementation Phase: Seaweed (seaweed) is weighed first then immersed and washed and then carried out an alkali process on the weight of seaweed that has been weighed mixed 10\% KOH with water ratio of 1: 6 then dried using an oven, conducted experiments with several levels of temperature, dry time and the number of ATS products in the oven dryer The maximum dryness level of this ATC product is 15\% water content according to SNI 8170: 2015 Alkali Treated Seaweed Chips, drying results are weighed again to find out its moisture content and know its yield, so that it can be seen visually yellow color chocolate and then the tensile gel test Strength $800 \mathrm{~min}$. Flow diagram of the experimental process can be described as follows 
Effect of Temperature, Time and Amount of Alkaline Treated Cotton Seaweed (ATS) Products Dried in a Dryer Oven on Product Quality

\section{Flow Process of experiment}

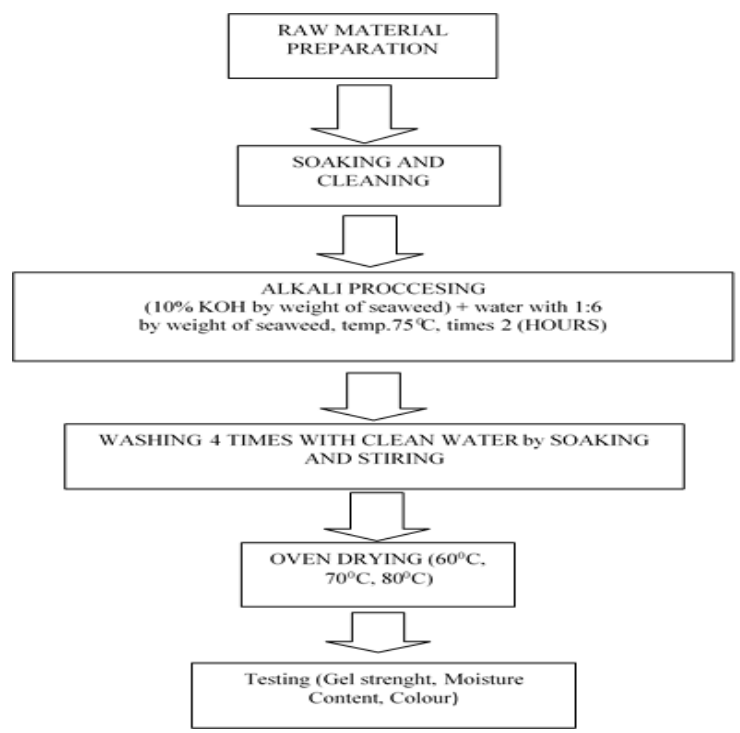

Fig. 1. Flow Process of Experiment

\section{Discussion}

The experiment was carried out with a combination of factors that influenced the results of the drying process in an oven. The data taken to assess the quality of the results of this drying process is the value of moisture content and gel strength which can be seen in table 3

TABLE 3. EXPERIMENT RESULTS OF DRYING PROCESS ALKALI TREATED COTTONY SEAWEED (ATS)

\begin{tabular}{|c|c|c|c|c|c|c|}
\hline \multirow[b]{2}{*}{ Combination } & \multicolumn{3}{|c|}{ Parameter } & \multirow[b]{2}{*}{ Experiment } & \multicolumn{2}{|c|}{ Result } \\
\hline & $\begin{array}{c}\text { Mass } \\
(\mathrm{kg})\end{array}$ & $\begin{array}{c}\text { Temperature } \\
\left({ }^{\circ} \mathrm{C}\right)\end{array}$ & $\begin{array}{c}\text { Time } \\
\text { (Minute) }\end{array}$ & & $\begin{array}{c}\text { Moisture } \\
\text { Content }(\%)\end{array}$ & $\begin{array}{c}\text { Gel } \\
\text { Strength }\end{array}$ \\
\hline \multirow{4}{*}{1} & & & & 1 & 14,0 & 810 \\
\hline & 0,5 & 60 & 240 & 2 & 14,2 & 800 \\
\hline & & & & 3 & 13,8 & 820 \\
\hline & & & & 1 & 13,8 & 900 \\
\hline \multirow[t]{3}{*}{2} & 0,5 & 70 & 320 & 2 & 13,6 & 910 \\
\hline & & & & 3 & 13,4 & 890 \\
\hline & & & & 1 & 14,9 & 874 \\
\hline \multirow[t]{3}{*}{3} & 0,5 & 80 & 400 & 2 & 14,7 & 870 \\
\hline & & & & 3 & 14,5 & 878 \\
\hline & & & & 1 & 14,7 & 855 \\
\hline \multirow[t]{3}{*}{4} & 1 & 60 & 320 & 2 & 14,8 & 850 \\
\hline & & & & 3 & 14,6 & 860 \\
\hline & & & & 1 & 12,2 & 840 \\
\hline \multirow[t]{3}{*}{5} & 1 & 70 & 400 & 2 & 12,1 & 820 \\
\hline & & & & 3 & 12,3 & 830 \\
\hline & & & & 1 & 13,8 & 810 \\
\hline \multirow[t]{3}{*}{6} & 1 & 80 & 240 & 2 & 13,6 & 820 \\
\hline & & & & 3 & 14,0 & 800 \\
\hline & & & & 1 & 14,5 & 820 \\
\hline \multirow[t]{3}{*}{7} & 1,5 & 60 & 400 & 2 & 13,9 & 830 \\
\hline & & & & 3 & 14,2 & 810 \\
\hline & & & & 1 & 13,5 & 820 \\
\hline \multirow[t]{2}{*}{8} & 1,5 & 70 & 240 & 2 & 13,6 & 830 \\
\hline & & & & 3 & 13,7 & 840 \\
\hline
\end{tabular}




\begin{tabular}{llllll}
9 & \multirow{2}{*}{1,5} & & 1 & 13,9 & 840 \\
& & 320 & 2 & 13,6 & 846 \\
& & & 3 & 13,7 & 843
\end{tabular}

The results of drying using an oven on seaweed as follows
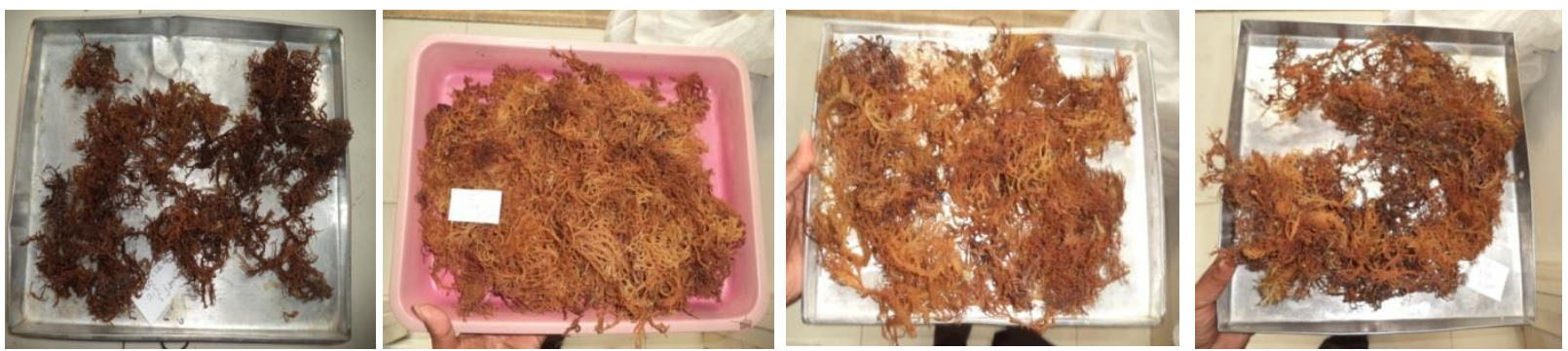

Fig. 2. Seaweed drying results

In accordance with the calculations that have been done, the value of the $\mathrm{S} / \mathrm{N}$ ratio obtained for each response was observed in each combination of factors. For the controlling factor of the identification of the influence of the level on the average value of moisture content (MC) and gel strength, the response data was obtained directly from the measurement results. Calculation of the average value of moisture content and gel strength through a combination of levels of each factor. For the response value of moisture content, the effect of its level can be seen in table 4 and for the response to the value of gel strength can be seen in table 5 The results of drying using an oven on seaweed as follows.

TABLE 4 S/N RESPOND OF MOISTURE CONTENT

\begin{tabular}{cccc}
\hline Level & Mass & Temperature & Time \\
\hline 1 & 17,02 & 16,89 & 17,20 \\
2 & 17,38 & 17,64 & 17,08 \\
3 & 17,18 & 17,03 & 17,29 \\
\hline Delta & 0,36 & 0,75 & 0,22 \\
\hline Rank & 2 & 1 & 3 \\
\hline
\end{tabular}

Response graphs based on the average results of $\mathrm{S} / \mathrm{N}$ ratio of moisture content can be seen in figure 3 .
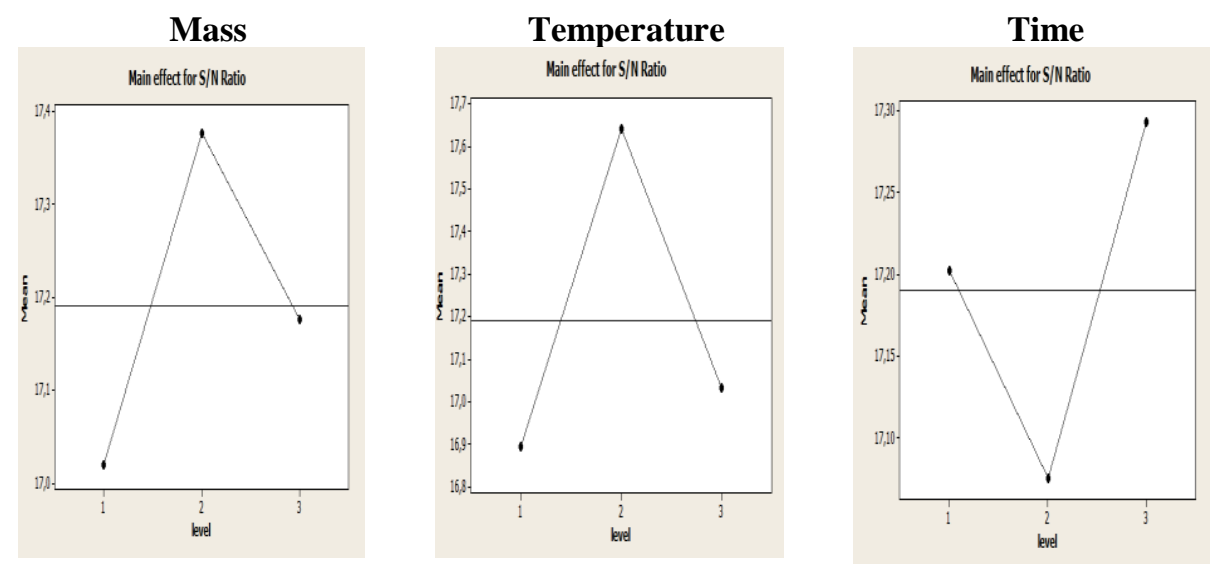

Fig. 3. S/N respond of moisture content

TABLE 5. S/N RESPOND OF GEL STRENGTH

\begin{tabular}{cccc}
\hline Level & Mass & Temperature & Time \\
\hline 1 & 58.70 & 58.36 & 58.24 \\
2 & 58.40 & 58.62 & 58.75 \\
3 & 58.39 & 58.51 & 58.50 \\
\hline Delta & 0.30 & 0.25 & 0.51 \\
\hline
\end{tabular}


Effect of Temperature, Time and Amount of Alkaline Treated Cotton Seaweed (ATS) Products Dried in a Dryer Oven on Product Quality

\begin{tabular}{llll}
\hline Rank & 2 & 3 & 1 \\
\hline
\end{tabular}

Respond based on average of $\mathrm{S} / \mathrm{N}$ ration for gel strength could be seen on figure 4.

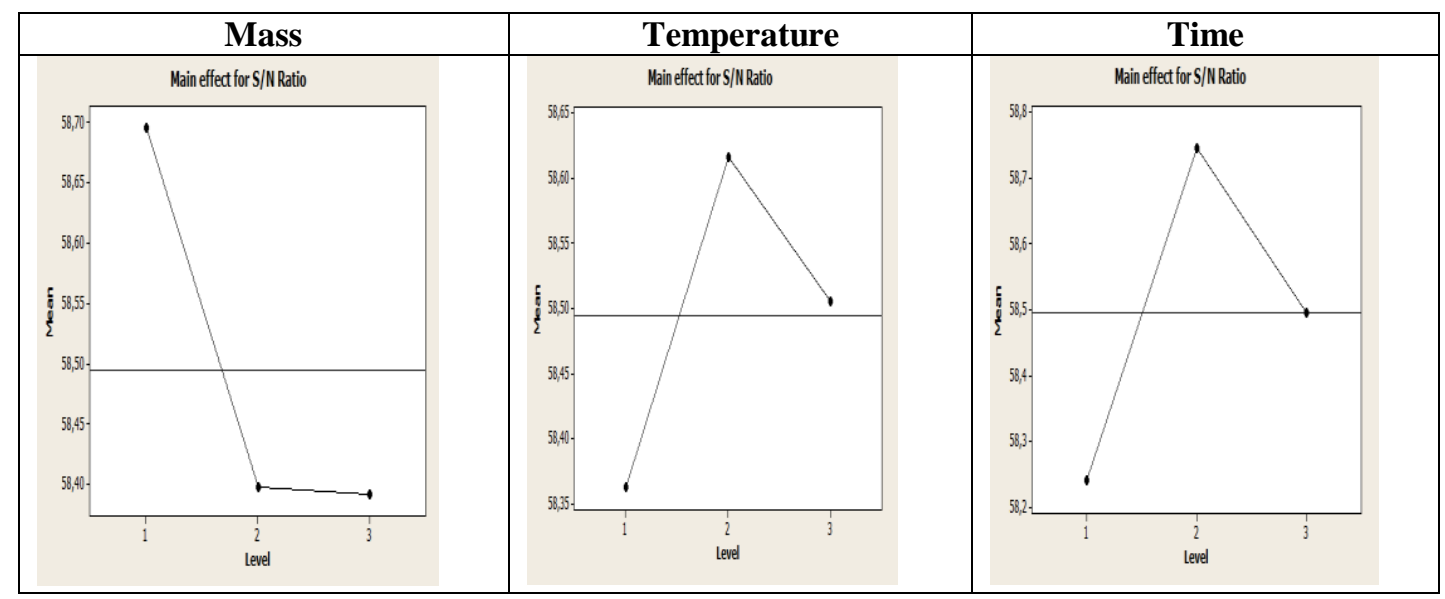

Fig. 4. S/N ration of gel strength

Based on table 4 and figure 3 what affects the moisture content response is temperature at level 1, weight at level 1 , and time at level 3 as in table 6 below.

TABLE 6 THE OPTIMUM RESPOND AFFECTS MOISTURE CONTENT

\begin{tabular}{ccc}
\hline Factor & Level & Value \\
\hline Mass & Level 2 & $1 \mathrm{~kg}$ \\
Temperature & Level 2 & $70^{\circ} \mathrm{C}$ \\
Time & Level 3 & 400 minutes \\
\hline
\end{tabular}

While the response that affects gel, strength is weight at level 2, temperature at level 1, drying time at level 1.

TABLE 7 THE OPTIMUM RESPOND AFFECTS GEL STRENGTH

\begin{tabular}{ccc}
\hline Factor & Level & Value \\
\hline Mass & Level 1 & $0.5 \mathrm{~kg}$ \\
Temperature & Level 2 & $70^{\circ} \mathrm{C}$ \\
Time & Level 2 & 320 minutes \\
\hline
\end{tabular}

Analysis of variants (ANOVA) is used to determine the process variables that have a significant effect. By using the Minitab software ANOVA response to moisture content with weight, temperature and drying time factors can be seen in Table 8

TABEL 8 ANALYSIS OF VARIANT FOR S/N RATIO OF MOISTURE CONTENT

\begin{tabular}{crrrrr}
\hline Variant & DF & \multicolumn{1}{c}{ Adj SS } & \multicolumn{1}{c}{ Adjs MS } & F-Value & \multicolumn{1}{c}{ P-Value } \\
\hline Mass & 2 & 0,1916 & 80,0954 & 0,30 & 0,77 \\
Temperature & 2 & 0,9528 & 0,4764 & $\mathbf{1 , 4 8}$ & 0,403 \\
Time & 2 & 0,0716 & 580,0335 & 0,11 & 0,9 \\
Error & 2 & 0,6427 & 0,3214 & & \\
\hline Total & 8 & 1,8587 & & & \\
\hline
\end{tabular}

The results of the analysis of variations in table 1.8 we can conclude several things. If the value of $\mathrm{P}>0.05$ means that these 3 factors are significant which influence moisture content. The biggest $\mathrm{F}$ value of the three factors tested was temperature, which was 1.48 , it means that the temperature had the greatest influence on the moisture content value.

Whereas ANOVA response of gel strength with weight, temperature and drying time factors can be seen in table 9 of the following ANOVA.

TABLE 9 ANALYSIS OF VARIANT FOR S/N RATIO OF GEL STRENGTH

\begin{tabular}{crrrrr}
\hline Variant & DF & \multicolumn{1}{c}{ Adj SS } & \multicolumn{1}{c}{ Adjs MS } & F-Value & \multicolumn{1}{c}{ P-Value } \\
\hline Mass & 2 & 0,18094 & 0,09047 & 1,75 & 0,363 \\
Temperature & 2 & 0,09754 & 0,04877 & 0,94 & 0,514
\end{tabular}




\begin{tabular}{cccccc} 
Time & 2 & 0,38455 & 0,19227 & $\mathbf{3 , 7 2}$ & 0,212 \\
Error & 2 & 0,10332 & 0,05166 & & \\
\hline Total & 8 & 0,76635 & & & \\
\hline
\end{tabular}

The greatest $F$ value of the three factors tested was drying time which was 3.72, it means that drying time had the greatest influence on the value of gel strength.

\section{CONCLUSION}

Based on the results of experiments and analyzes that have been done, the following conclusions are obtained:

1. The combination of significant drying process parameters for moisture content is as follows:
a. Weight on level 2 is $1 \mathrm{~kg}$.
b. The temperature level at level 2 is $70{ }^{\circ} \mathrm{C}$.
c. Drying time at level 3 is 400 minutes.

2. The combination of significant process parameters for the strength gel is as follows:
a. Weight at level 1 is $0.5 \mathrm{~kg}$.
b. The temperature level at level 2 is $70{ }^{\circ} \mathrm{C}$.
c. Drying time at level 2 is 320 minutes.

3. The most significant drying process parameter to minimize moisture content is the temperature level.

4. The most significant drying process parameter to maximize gel strength is the drying time

\section{REFERENCES}

[1] Kementrian kelautan dan Perikanan (KKP), "Statistik Perikanan Indonesia". Kementrian Kelautan dan Perikanan, Jakarta, 2012.

[2] S.Wibowo,M.Darmawan,A.R.Hakim,S.Marsella,"Effect of Chopping Step and Drying Technique on The Quality of Alkali Treated Cottonii (ATC),'Jurnal Squalen, Vol17,No3 Desember 2012, hal. 123-130

[3] Denni Kartika Sari, Indar Kustiningsih, Retno Dhamar Lestari,"Pengaruh Suhu dan Waktu Pengeringan Terhadap Mutu Rumput Laut Kering,’Jurnal TEKNIKA, Vol.13, No.1 juni 2017,hal. 43-50

[4] Fifi Arfini,’Optimasi Proses Pembuatan Karaginan Dari Rumput Laut Merah (Euchema Cottonii),’Jurnal Galong Tropika,Januari 2013,hal.2332.

[5] S.Nurmiah, R.Syarief, Sukarno, R.Peranginangin, B.Nurtama"Response Surface Methodology Pada Optimalisasi Kondisi Proses Pengolahan Alkali Treated Cottonii (ATC),’Jurnal JPB Kelautan dan Perikanan,vol 8.No1,2013: 9-22.

[6] Shilpi Gupta, Sabrina Cox,Nissreen Abu-Ghannam,"Effect of defferent Drying temperatures on the Moisture and Phytochemmical Constituents of Edible Irish Brown Seaweed, Food Science and Technology, "jurnal LWT-Food Science and Technology, 2011, 1-7.

[7] Fadilah, S.Distantina, Dhian B.P, Rahmah.M, YC.Danarto, Wiratni, M.Fahrurrozi,"Pengaruh Metode Pengeringan Terhadap Kecepatan Pengeringan dan Kualitas Karagen Dari Rumput Laut Eucheuma Cottonii," Seminar Rekayasa Kimia dan Proses, UNDIP Semarang: Agustus 2010,C-01-6.

[8] Denny K.S, Indar.K, Retno S.D.L,” Pengaruh Suhu dan Waktu Pengeringan Terhadap Mutu Rumput Laut Kering,” Jurnal TEKNIKA, Vol 13,No 1, Juni 2017 hal 43-50.

[9] Arun S.Mujandar.et al. "Hand book of industrial Drying” $2^{\text {end }}$ Edition Marcell Deker, New York,1995.

[10] A.Fudholi, M.Y,Othman, M.H Ruslan, M.Yahya, A.Zaharim, K. Sopian, "Design and Testing of solar for drying and kinetics of seaweed in Malaysia" Researches in geography, Geology,Energy,Environment and Biomedicine, May 2011,119-124.

[11] Shabrina Z.U, Wahono.H.S,"Pengaruh suhu dan lama Pengeringan Dengan Metode Cabinet dryer Terhadap Karekteristik Manisan Apel Varietas ANNA," Jurnal Pangan dan Agroindustri, Vol.5,No.3, 2017,hal 60-71.

[12] Mohamad Djaeni,A Prasetyaningrum,’Pengeringan Keraginan dari Rumput Laut Eucheuma Cottonii Pada Spray Dryer Menggunakan udara yang di Dehumidifikasi Dengan Zeodit Alam,Tinjauan Kualitas Produk dan Efesiensi Energi,"Jurnal Momentum,vol.8, No.2 Oktober 2012, hal.28-34

[13] Soejanto I.(2009). Desain Eksperimen Dengan Metode Taguchi,Jakarta, Graha Ilmu 